\title{
First report of grapevine fleck virus in vineyards of Bosnia and Herzegovina
}

\author{
Ana Crnogorac ${ }^{1} \cdot$ Mladen Gašpar $^{1} \cdot$ Salvatore Davino $^{2} \cdot$ Ana Mandić $^{3} \cdot$ Slavica Matić $^{4}$
}

Received: 1 May 2020 / Accepted: 21 May 2020 / Published online: 29 May 2020

(C) Società Italiana di Patologia Vegetale (S.I.Pa.V.) 2020

Keywords GFkV · Vitis vinifera $\cdot$ Autochthonous cultivars · DAS-ELISA · RT-PCR

Grapevine is one of the most important fruit crops in Bosnia and Herzegovina with an annual production of around 40 thousand tons in 2018 (FAOSTAT, http://www.fao.org/ faostat/en/\#data/QC). Production of grapevine in the country is mainly concentrated in vineyards in the Lištica and Mostar regions of Herzegovina with the two predominant autochthonous cultivars 'Žilavka' and 'Blatina'. Grapevine fleck virus (GFkV) from the genus Maculavirus in the family Tymoviridae is a phloem limited virus with a positive-sense single-stranded RNA genome (Dreher et al. 2012). GFkV is associated with fleck disease of Vitis spp.

In order to investigate the current status of GFkV in Bosnia and Herzegovina, 80 grapevine shoot samples were randomly collected in autumn 2018 from vineyards located in the Mostar region. Samples of Žilavka' and 'Blatina' were tested by DAS-ELISA using GFkV specific antibodies (Bioreba, Switzerland). The same samples were used for total RNA extraction and RT-PCR assays (Shi et al. 2003; Gambino and Gribaudo 2006) to amplify a 353-bp and a 179-bp of the replicase and the coat protein $(\mathrm{CP})$ genes, respectively.

Serological and molecular analyses were consistent and showed that $20(25 \%)$ out of the 80 samples were infected with GFkV. GFkV-positive samples were randomly selected (two from each cultivar) and directly sequenced. Sequences were

Slavica Matić

slavica.matic@unito.it

1 Federal Agromediterranean Institute of Mostar, Biskupa Čule 10, 88000 Mostar, Bosnia and Herzegovina

2 Department of Agricultural, Food and Forest science, University of Palermo, Viale delle Scienze, Ed. 4, 90128 Palermo, PA, Italy

3 Faculty of Agriculture and Food Technology, University of Mostar, 88000 Mostar, Bosnia and Herzegovina

4 Department of Agricultural, Forest and Food Sciences, University of Torino, Largo P. Braccini 2, Grugliasco, TO 10095, Italy deposited to GenBank as accession numbers MT386073MT386080. Blastn analysis showed 98-99\% nucleotide identity with previously reported GFkV isolate SK121 (JN133957) from Slovakia and 98-99\% nucleotide identity with GFkV isolate GFV-HUPH (MF446642) from Hungary in the CP and replicase genes, respectively. GFkV was detected in symptomatic vines showing downward leaf rolling where a simultaneous presence of grapevine leafroll-associated viruses 1 and/or -3 was found by additional ELISA assays. To our knowledge, this is the first report of GFkV in Bosnia and Herzegovina.

\section{Compliance with ethical standards}

This article does not contain any studies with human participants or animals performed by any of the authors.

Conflict of interest No potential conflict of interest was reported by the authors.

Informed consent Informed consent was obtained from all individual participants included in the study.

\section{References}

Dreher TW, Edwards MC, Gibbs AJ, Haenni A-L, Hammond RW, Jupin I, Koenig R, Sabanadzovic S, Martelli GP (2012) Family Tymoviridae. In: King AMQ, Adams MJ, Carstens EB, Lefkowitz EJ (eds) Virus Taxonomy: Ninth Report of the International Committee on Taxonomy of Viruses. Elsevier Academic Press, San Diego, pp 944-952

Gambino G, Gribaudo I (2006) Simultaneous Detection of Nine Grapevine Viruses by Multiplex Reverse TranscriptionPolymerase Chain Reaction with Coamplification of a Plant RNA as Internal Control. Phytopathology 96:1223-1229

Shi BJ, Habili N, Symons RH (2003) Nucleotide sequence variation in a small region of the Grapevine fleck virus replicase provides evidence for two sequence variants of the virus. Ann Appl Biol 142:349-355

Publisher's note Springer Nature remains neutral with regard to jurisdictional claims in published maps and institutional affiliations. 